\title{
Evaluation of the Regional-Scale Optimal K Rate Based on Sustainable Apple Yield and High-Efficiency K Use in Loess Plateau and Bohai Bay of China: A Meta-Analysis
}

\author{
Wenzheng Tang $\mathbb{D}^{\mathbb{D}}$, Wene Wang, Dianyu Chen, Ningbo Cui, Haosheng Yang and Xiaotao Hu * \\ Key Laboratory of Agricultural Soil and Water Engineering in Arid and Semiarid Areas, Ministry of Education, \\ Northwest A \& F University, Xianyang 712100, China; tangwzh116@nwsuaf.edu.cn (W.T.); \\ wangwene@nwsuaf.edu.cn (W.W.); dianyuchen@nwsuaf.edu.cn (D.C.); cuiningbo@126.com (N.C.); \\ haoshengY@nwafu.edu.cn (H.Y.) \\ * Correspondence: huxiaotao11@nwsuaf.edu.cn; Tel.: +86-0298-709-2129
}

check for updates

Citation: Tang, W.; Wang, W.; Chen, D.; Cui, N.; Yang, H.; Hu, X.

Evaluation of the Regional-Scale Optimal K Rate Based on Sustainable Apple Yield and High-Efficiency K Use in Loess Plateau and Bohai Bay of China: A Meta-Analysis. Agronomy 2021, 11, 1368. https://doi.org/ 10.3390/agronomy11071368

Academic Editor: Joëlle Fustec

Received: 12 May 2021

Accepted: 29 June 2021

Published: 5 July 2021

Publisher's Note: MDPI stays neutral with regard to jurisdictional claims in published maps and institutional affiliations.

Copyright: (c) 2021 by the authors. Licensee MDPI, Basel, Switzerland. This article is an open access article distributed under the terms and conditions of the Creative Commons Attribution (CC BY) license (https:/ / creativecommons.org/licenses/by/ $4.0 /)$.

\begin{abstract}
In order to meet the growing food demand of the global population and maintain sustainable soil fertility, there is an urgent need to optimize fertilizer application amount in agricultural production practices. Most of the existing studies on the optimal K rates for apple orchards were based on case studies and lack information on optimizing K-fertilizer management on a regional scale. Here, we used the method of combining meta-analysis with the K application rate-yield relationship model to quantify and summarize the optimal $\mathrm{K}$ rates of the Loess Plateau and Bohai Bay regions in China. We built a dataset based on 159 observations obtained from 18 peer-reviewed literature studies distributed in 15 different research sites and evaluated the regional-scale optimal $\mathrm{K}$ rates for apple production. The results showed that the linear plus platform model was more suitable for estimating the regional-scale optimal $\mathrm{K}$ rates, which were 208.33 and $176.61 \mathrm{~kg} \mathrm{~K} \mathrm{ha}^{-1}$ for the Loess Plateau and Bohai Bay regions of China, respectively. Compared with high $\mathrm{K}$ application rates, the optimal K rates increased K use efficiency by $45.88-68.57 \%$, with almost no yield losses. The optimal $\mathrm{K}$ rates also enhanced the yield by $6.30 \%$ compared with the low $\mathrm{K}$ application rates.
\end{abstract}

Keywords: optimal K rates; K use efficiency; yield; apple orchards

\section{Introduction}

Apple is the fourth most important fruit crop in the world after all citrus, grapes, and bananas and widely distributed around the world, especially in China, due to its strong adaptability to the growing environment [1]. Delicious and nutritious apples are a kind of fruit that everyone eats widely in daily life [2,3]. The per capita consumption of apples in the world increased sharply from $2.1 \mathrm{~kg}$ in 2008 to $9.2 \mathrm{~kg}$ in 2013 [4,5]. The global population is expected to reach 9 billion by the mid-21st century [6]. Responding to the future apple demand originated from the rapid population growth will require increasing apple yields without expanding orchard areas and increasing environmental risks while maintaining soil fertility. China is the largest apple producer in the world [7-10]. As of 2013, the annual fresh apples yields were about 39.7 million tons, and the planting area was 2.41 million hectares, accounting for 49 and $46 \%$ of the world's apple yields and planting area, respectively [5]. Apple growth requires not only suitable soil and climatic conditions [11,12] but also a reasonable fertilization strategy necessary for maintaining a sustainable apple production $[13,14]$. Irrational fertilization, especially insufficient fertilization, will inevitably cause yield loss [15]. Potassium $(\mathrm{K})$ is an essential nutrient element in the physiological growth process of apples [16-18], increasing the yield and quality of apples [19,20] by participating in important biochemical processes such as photosynthesis [15,21-23], various enzyme activation [24-27], protein synthesis [15], sugar transport [28] and stomatal activity [29]. However, many farmers in poverty-stricken areas, especially in Africa, did not apply K 
due to the sky-high cost of K-fertilizer [30], resulting in K deficiency in large areas of farmland [31,32], making $\mathrm{K}$ a key limiting factor in agro-production in the region [33]. In view of the irreplaceability of K-fertilizer in apple production, rational K-fertilizer management is an important agronomic practice to increase apple yield and maintain soil $\mathrm{K}$ fertility.

However, the rational $\mathrm{K}$ application rate for apple production varies greatly among the research results of different regions. So much, in fact, that the optimal $\mathrm{K}$ rate at the regional scale required for raising yield is not easy to forecast, and K-fertilizer is usually applied in production practices higher than the amount needed by crops. Excessive K-fertilizer application reduces the absorption of cations such as calcium, magnesium by crops [29], destroys the nutritional structure and balance in the soil, aggravates the deterioration of soil fertility [34], weakens crop productivity, and causes apple 'bitter pit disease' [35-37]. These negative impacts are very detrimental to the sustainable development of agricultural systems. K use efficiency (KUE) is usually used to evaluate excessive K application [38], defined as the ratio of yield to corresponding K application. Globally, high KUE is needed to improve the sustainable development of an agricultural system. However, the estimated global KUE for cereal production is only 19\% [39], indicating that excessive K application may lead to significant loss of $\mathrm{K}$ (e.g., leaching or erosion) and serious problems with low KUE [40]. Li et al.'s [41] research on Red Fuji apple in Shaanxi showed that on the basis of applying nitrogen and phosphorus fertilizer, the yield increased at a decreasing rate with an increase in K application rate, and the amount of K-fertilizer had appropriate limits. Furthermore, Jin et al. [42] found that the yield of Red Fuji apple improved with an increase in $\mathrm{K}$ application rate below a certain value and exceeded this value, resulting in a decrease in yield. Therefore, a reasonable $\mathrm{K}$ application rate is an effective method to maintain crop yield and improve KUE.

We have been facing the serious unscientific application of K-fertilizer in most regions for a long time and the social, economic, ecological, and environmental problems caused by it, determining that the appropriate $\mathrm{K}$ application rate has become one of the hot topics in agriculture in the world today [43-45]. Although there were many studies on the effect of K-fertilizer on apple yield based on field experiments, these results were applicable to specific sites rather than large-scale agro-ecological regions.

Apple is an important economic fruit crop in China. Considering the biological characteristics, meteorological conditions, and geographic locations, China was divided into four different apple cultivation regions: Loess Plateau, Bohai Bay, the old channel of the Yellow River, and the Southwest Cold Highland (Figure 1). In the four apple cultivation regions, the Loess Plateau and Bohai Bay are the two major apple-producing regions in China [46], and they are recognized by the United Nations Food and Agriculture Organization as the world's best eugenic regions for apples, maintaining their green and sustainable development in the soil-environment system. It is an important foundation for meeting people's living quality needs and maintaining the international competitiveness of China's apple industry. Based on this, this study focuses on these two regions.

To the best of our knowledge, the method of combining meta-analysis with a yieldfertilizer relational model had not been attempted to evaluate and quantify the regionalscale optimal $\mathrm{K}$ rate based on the sustainability of apple yield in the two major appleproducing regions of the Loess Plateau and Bohai Bay in China recently. A meta-analysis helps to identify specific data patterns only when data from a wide range of agronomic conditions and production systems are combined and analyzed in environmental and agronomic contexts [47]. In the present study, by means of meta-analysis we aim to integrate the published literature and establish the data sets of apple yield, $\mathrm{K}$ application rate, and KUE in the Loess Plateau and Bohai Bay of China and reveal the regional-scale optimal $\mathrm{K}$ rate for maintaining apple yield and improving KUE. We intended to settle the following confusions: (1) What are the regional-scale optimal $\mathrm{K}$ rates in apple cultivation areas in the Loess Plateau and Bohai Bay in China? (2) What is the relationship between indigenous K supply (IKS) and K application? (3) How will apple yield and KUE change if the regional-scale optimal $\mathrm{K}$ rate is applied? 


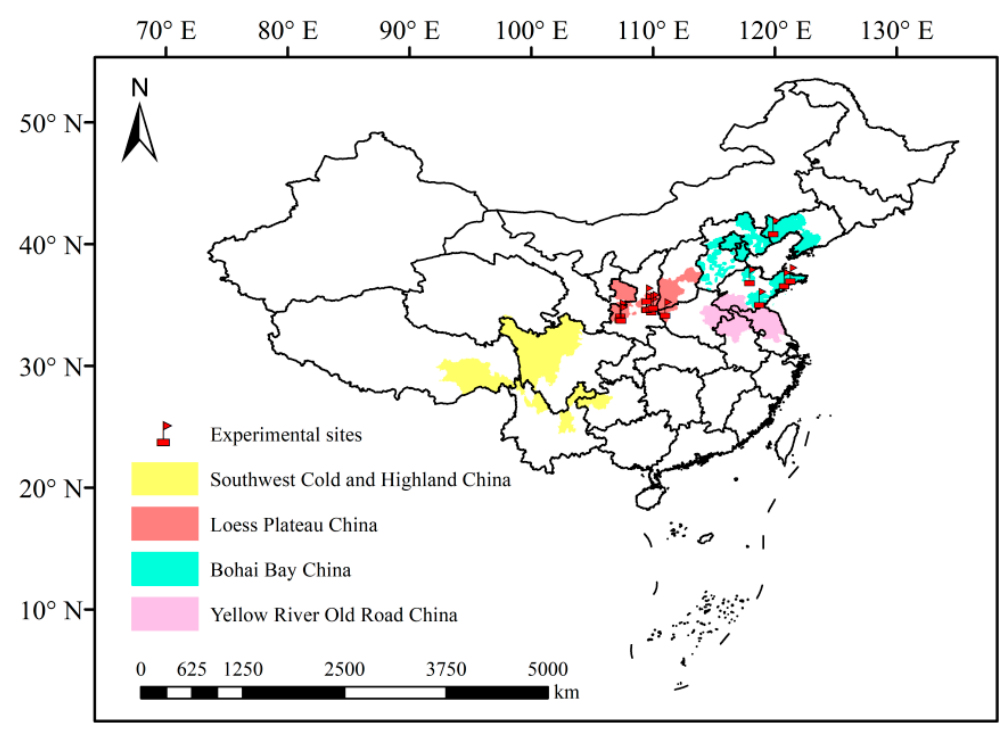

Figure 1. Geo-location of the four major apple cultivation areas in China and the specific apple orchard test sites in the literature compiled by meta-analysis.

\section{Materials and Methods}

\subsection{Study Region}

The Loess Plateau is located in the (warm) temperate (continental) monsoon climate zone, with cool climate (average annual temperature (AAT) is $9-11^{\circ} \mathrm{C}$ ), sufficient light, large diurnal temperature range, moderate rainfall (average annual rainfall (AAR) is 572$664 \mathrm{~mm}$ ), and the texture is mainly yellow loamy soil and black loessial soil, which is an ideal place for apple growth and development. The region mainly cultivates latematuring apple varieties such as colored systems Fuji, Xinhongxing, Jonagold, and Marsha, accounting for 57.2 and $53.0 \%$ of China's planting areas and yields, respectively. The Bohai Bay is located in the continental monsoon climate zone, including two sub-regions of inland and offshore. The former is suitable for the growth of early-medium ripe apples due to its mild climate (AAT is $12-13{ }^{\circ} \mathrm{C}$ ), sufficient light and proper rainfall (AAR is $580-740 \mathrm{~mm}$ ), while the latter is suitable for the growth of mid-late maturing apples due to its cold summer and long autumn (AAT is $9-12{ }^{\circ} \mathrm{C}$ ), sufficient light and abundant rainfall (AAR is $580-840 \mathrm{~mm}$ ). The texture is brown soil. The region mainly develops varieties of coloring systems such as Fuji, Marshal, Jonagold, Golden Dwarf, and Xinhongxing, accounting for 26.9 and $36.0 \%$ (2018) of China's planting areas and yields, respectively. The Geo-location, specific apple orchard test sites, and some basic soil physicochemical properties of the two study areas were shown in Figure 1 and Table 1, respectively.

Table 1. Basic soil information at regional scale in apple planting regions of China's Loess Plateau and Bohai Bay.

\begin{tabular}{ccc}
\hline Regions & Loess Plateau & Bohai Bay \\
\hline Available $\mathrm{N}\left(\mathrm{mg} \mathrm{kg}^{-1}\right)$ & 9.2 to 47.8 & 48.5 to 100.9 \\
Available $\mathrm{P}\left(\mathrm{mg} \mathrm{kg}^{-1}\right)$ & 9.1 to 55.9 & 5.7 to 31.0 \\
Available $\mathrm{K}\left(\mathrm{mg} \mathrm{kg}^{-1}\right)$ & 65.6 to 184.0 & 48.9 to 155.4 \\
Organic matter $\left(\mathrm{g} \mathrm{kg}^{-1}\right)$ & 6.9 to 67.4 & 3.7 to 15.2 \\
soil $\mathrm{PH}$ & 8.2 to 8.3 & 5.6 to 8.2 \\
\hline
\end{tabular}

\subsection{Data Collection and Dataset Establishment}

A search of peer-reviewed published papers was performed to collect data on the effects of K-fertilizer on apple yield in China up to December 2020. The search terms 'apple + fertilization (or water-fertilizer or K)' were used in the China Knowledge Resource Integrated Database and the Web of Science to find articles that did not include conference 
records and postgraduate dissertation. For each citation, we reviewed the titles, abstracts, and test scheme to select articles that met the following criteria: (1) it must be a field experiment, (2) "no K-fertilizer input" was used as a control, and various K rates were used as other treatments, (3) there was at least one pair of control and treatment data, and (4) all the other experimental conditions were consistent or similar in a given experiment except for different $\mathrm{K}$ rates. Based on the above criteria, a total of 212 observation data were collected from 18 articles covering the Loess Plateau and Bohai Bay in China.

For each extracted observation from the selected articles, we compiled the following information: experimental location (expressed in latitude and longitude), average annual rainfall, average annual temperature, soil texture, and available N, P, K. Different studies reported available N, P and K in different depth (ranged from 0-10 to 0-60 cm) soil layers, with the majority of studies focused on $0-40 \mathrm{~cm}$. When the study reported multiple depths, we selected the average value of available N, P, and K across depths to $40 \mathrm{~cm}$.

In the test data distribution, we excluded 16 measured values in which the apple yield of the $\mathrm{K}$ fertilized plot was less than that of the control because it obviously violated the widely recognized theory of fertilizer production increase. The measured values of yield $<9 \mathrm{t} \mathrm{ha}^{-1}$ (18 data points in the Loess Plateau) and $>46 \mathrm{t} \mathrm{ha}^{-1}$ (10 in the Loess Plateau and 9 in the Bohai Bay) were also deleted because they were probably obtained under the background of extreme weather and unreasonable management of orchards, and therefore could not represent a wide range of climate and orchard management practices. Finally, the dataset we established for the study of the relationship between apple yield and $\mathrm{K}$ fertilization rates (from 0 to different $\mathrm{K}$ fertilizer inputs) includes 159 observation data from 18 articles (45 for 6 articles in the Bohai Bay and 114 for 12 articles in the Loess Plateau).

\subsection{Data Calculation}

\subsubsection{Indigenous K Supply}

Soil indigenous K supply (IKS) refers to a plant's uptake of K in the treatments without $\mathrm{K}$ fertilization [48] and reflects soil basic K supply capacity before $\mathrm{K}$ application. IKS is crucial for formulating a K-management strategy and is especially suitable for large-scale areas with similar cropping systems and management practices [49]. Considering that IKS represented the inherent K-fertilizer status of the soil, it was considered to be an important factor in determining a reasonable $\mathrm{K}$ rate. Nitrogen and phosphate fertilizer application rates among different treatments in each field study reported in the peer-reviewed articles screened based on criteria were reasonable and fixed, with different $\mathrm{K}$ rates as the only variable. Without K-fertilizer, the K required for the growth and development of apples could only rely on soil indigenous K supply (IKS). Therefore, we selected apple yields $\left(\mathrm{t} \mathrm{ha}^{-1}\right)$ under no $\mathrm{K}$ fertilization treatment to characterize IKS [50].

\subsubsection{K Fertilizer Efficiency}

In this study, the use efficiency (KUE) and agronomic efficiency (KAE) of K were used to evaluate the application of different levels of K-fertilizer. KUE was defined as the ratio of plant yield to K rate and expressed as K-fertilizer's use capacity. KAE is defined as the ratio of increase in plant yield between a $\mathrm{K}$ fertilized field and a control field to $\mathrm{K}$ rate and revealed the productivity of K-fertilizer. KUE $\left(\mathrm{t} \mathrm{kg}^{-1}\right)$ and $\mathrm{KAE}\left(\mathrm{t} \mathrm{kg}^{-1}\right)$ were therefore calculated [51-54] as follows:

$$
\begin{gathered}
\mathrm{KUE}=\frac{Y_{K T}}{F_{K T}} \\
\mathrm{KAE}=\frac{Y_{K T}-Y_{K C}}{F_{K T}}
\end{gathered}
$$

where $Y_{K T}\left(\mathrm{t} \mathrm{ha}^{-1}\right)$ is the yield in the $\mathrm{K}$ fertilized field, $Y_{K C}\left(\mathrm{t} \mathrm{ha}{ }^{-1}\right)$ is the plant yield in the control field, and $F_{K T}\left(\mathrm{~kg} \mathrm{~K} \mathrm{ha}^{-1}\right)$ is the total $\mathrm{K}$ fertilizer application rates. 


\subsection{Data Analysis}

\subsubsection{Statistical Evaluation of Fertilizer Efficiency Models}

The fertilizer efficiency model is an effective method to guide agricultural production while taking into account the ecological environment and economic benefits. Most of the existing studies were conducted at the field scale. In order to explore the applicability of different fertilizer efficiency models at the regional scale, the linear $(\mathrm{L})$, quadratic $(\mathrm{Q})$, linear-plus-platform $(\mathrm{L}+\mathrm{P})$, and quadratic-plus-platform $(\mathrm{Q}+\mathrm{P})$ models were used to describe the response of apple yield to K-fertilizer rate in the Loess Plateau and Bohai Bay area of China. In the fertilizer efficiency models, the K-fertilizer rate $\left(x, \mathrm{~kg} \mathrm{~K} \mathrm{ha}^{-1}\right)$ in each field experiment was used as an independent variable, and the corresponding apple yield $\left(\mathrm{y}, \mathrm{t} \mathrm{ha}^{-1}\right)$ was used as a dependent variable. For the linear model, $\mathrm{Y}$ increased linearly with increasing $\mathrm{x}$. For the quadratic model, $\mathrm{y}$ increased curvedly with increasing $\mathrm{x}$ ranging from 0 to a critical value and then decreased with the increasing $\mathrm{x}$ beyond the critical value. For the linear-plus-platform model, $\mathrm{Y}$ increased linearly with increasing $\mathrm{x}$ ranging from 0 to a critical value and reached the maximum at the critical value; after exceeding the critical value, $\mathrm{y}$ remained the maximum no matter how $\mathrm{x}$ increased. For the quadratic-plus-platform model, $y$ increased curvedly with increasing $\mathrm{x}$ ranging from 0 to a critical value and reached the maximum at the critical value; after exceeding the critical value, $y$ remained the maximum no matter how $\mathrm{x}$ increased.

L model function expression was:

$$
\mathrm{y}=\mathrm{u}+\mathrm{vx}
$$

where $\mathrm{u}$ and $\mathrm{v}$ are the intercept and coefficient of the linear function, respectively.

$Q$ model function expression was:

$$
y=a+b x+c x^{2}
$$

where $b$ and $c$ are the quadratic fitting coefficients, and $a$ is the quadratic intercept.

$\mathrm{L}+\mathrm{P}$ model function expression was:

$$
y= \begin{cases}k x+t, & \text { if } x<x_{o p t} \\ y_{\max }, \text { if } x \geq x_{\text {opt }}\end{cases}
$$

where $k$ and $t$ are the linear fitting coefficient and intercept, respectively, and $x_{o p t}$ is the critical $\mathrm{K}$ rate at the intersection of the linear function and the platform straight line, corresponding to the maximum yield $\left(y_{\max }\right)$.

$\mathrm{Q}+\mathrm{P}$ model function expression was:

$$
y= \begin{cases}\alpha+\beta x+\gamma x^{2}, & \text { if } x<x_{o p t} \\ y_{\max } & \text { if } x \geq x_{o p t}\end{cases}
$$

where $\alpha$ and $\beta$ (and $\gamma$ ) are the intercept and coefficients of the quadratic fitting, respectively, and $x_{o p t}$ is the critical $\mathrm{K}$ rate at the intersection of the quadratic curve and the platform line, corresponding to the maximum yield $\left(y_{\max }\right)$.

Calculating the root mean square error (RMSE) according to Wang et al. [55] description:

$$
\operatorname{RMSE}(\%)=\frac{100}{\bar{O}} \times \sqrt{\frac{\sum_{i=1}^{n}\left(O_{i}-P_{i}\right)^{2}}{n}}
$$

where $n$ is the sum total of the tested and simulated data pairs, $O_{i}$ and $P_{i}$ are the tested and corresponding simulated values, respectively, and $\bar{O}$ is the tested mean.

Evaluation indicators of the four relationship models between apple yield and $\mathrm{K}$ application in China's Loess Plateau and Bohai Bay apple cultivation areas were counted in Table 2. The statistical evaluation indexes $R^{2}$ and RMSE were used to explain the apple yield-K rate relationship models and to measure the models' performance. $R^{2}$ represented 
the goodness of fit of the model and reflected the proportion that all variation of yields could be explained by the model (i.e., the yield-K rate relationship model) in our research, a larger $R^{2}$ value indicated a more accurate model. RMSE described the dispersion degree of a set of datasets, which reflected the operational stability of the model in a region-specified in our research, a smaller RMSE value indicated a smaller difference between the actual value and the corresponding simulated value, and a more stable model. Hence, larger $R^{2}$ and smaller RMSE values were used as the criteria for screening a reasonable model in our study. Table 2 showed that the $R^{2}$ values of the $L+P$ and $Q+P$ models were both higher than those of the $\mathrm{L}$ and $\mathrm{Q}$ models. Meanwhile, the $\mathrm{L}+\mathrm{P}$ and $\mathrm{Q}+\mathrm{P}$ models had smaller RMSE values than the $L$ and $Q$ models. However, the differences in $R^{2}$ and RMSE between the $\mathrm{L}+\mathrm{P}$ and $\mathrm{Q}+\mathrm{P}$ models were very small. Compared with the $\mathrm{L}$ and $\mathrm{Q}$ models, the $\mathrm{L}+\mathrm{P}$ and $\mathrm{Q}+\mathrm{P}$ models were more suitable to describe the response curve of the relationship between apple yield-K application rates so as to provide a reasonable estimate of K-fertilizer input. Finally, we compared the results of the two models $(\mathrm{L}+\mathrm{P}$ and $\mathrm{Q}+\mathrm{P}$ models) to determine the optimal $\mathrm{K}$ rate for obtaining high KUE and maintaining apple yield.

Table 2. Evaluation indicators of the four kinds of relationship models between apple yield and $\mathrm{K}$ application rates.

\begin{tabular}{cccccc}
\hline Regions & Statistics & L Model & Q Model & Q + P Model & L + P Model \\
\hline \multirow{4}{*}{ Loess Plateau } & RMSE (\%) & 19.85 & 19.73 & 19.56 & 19.38 \\
& $R^{2}$ & 0.153 & 0.156 & 0.182 & 0.191 \\
& P value & $<0.001$ & $<0.001$ & $<0.001$ & $<0.001$ \\
Bohai Bay & RME (\%) & 10.45 & 9.77 & 10.20 & 10.16 \\
& $\mathrm{R}^{2}$ & 0.249 & 0.324 & 0.351 & 0.351 \\
& P value & $<0.001$ & $<0.001$ & $<0.001$ & $<0.001$ \\
\hline
\end{tabular}

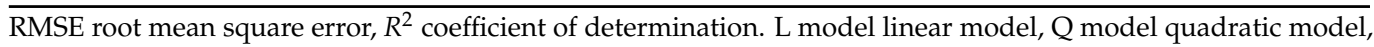
$\mathrm{Q}+\mathrm{P}$ model quadratic-plus-platform, $\mathrm{L}+\mathrm{P}$ model linear-plus-platform.

\subsubsection{Statistical Analysis}

A statistical analysis should first test the data distribution, using a Shapiro-Wilk test to test the normality of the residuals. Due to the original yields, KUE and KAE data did not obey the normal distribution. Therefore, we used SPSS 24.0 (SPSS Statistics, IBM, Chicago, IL, USA) to perform a square root conversion of the yields, KUE and KAE, and still used the original data for analysis after meeting the normal distribution. To screen the best curve that defined the response of the yield to the K-fertilizer rate, SPSS 24.0 was used to quantify the $\mathrm{L}, \mathrm{Q}, \mathrm{L}+\mathrm{P}$, and $\mathrm{Q}+\mathrm{P}$ relationship between yield and $\mathrm{K}$ application. In addition, an exponential function was used to simulate the response of $\mathrm{K}$ rate to KUE and KAE using SPSS 24.0. We created the graphics and tables using OriginPro 2021(OriginLab, Northampton, MA, USA) and the Microsoft Office software, respectively. The map was drawn by the ArcGis 10.2 software (Esri, Redlands, CA, USA).

\section{Results and Discussion}

\subsection{Comparison of Models and Determination of Optimum K Rate}

One of the key objectives of agricultural production was to maximize crop yields with minimal fertilizer inputs $[56,57] . \mathrm{K}$ is a macronutrient element necessary for apple production $[38,58]$. The $\mathrm{L}+\mathrm{P}$ and $\mathrm{Q}+\mathrm{P}$ models were used to analyze the mutual response relationship between apple yield and $\mathrm{K}$ application rates in Bohai Bay and the Loess Plateau of China (Figure 2). The average apple yield for the Bohai Bay region (30.78 tha $\left.\mathrm{t}^{-1}\right)$ was much higher than that for the Loess Plateau region $\left(27.62 \mathrm{t} \mathrm{ha}^{-1}\right)$. The critical $\mathrm{K}$ application rate corresponding to the maximum estimated yield based on the $\mathrm{Q}+\mathrm{P}$ model was $276.93 \mathrm{~kg} \mathrm{~K} \mathrm{ha}^{-1}$ for the Loess Plateau and $382.65 \mathrm{~kg} \mathrm{~K} \mathrm{ha}^{-1}$ for Bohai Bay, and 208.33 and $176.61 \mathrm{~kg} \mathrm{~K} \mathrm{ha}^{-1}$ for the $\mathrm{L}+\mathrm{P}$ model, respectively. In the study area, the maximum yield predicted by the $\mathrm{Q}+\mathrm{P}$ model was only $0-5.21 \%$ higher than that predicted by the $\mathrm{L}+$ 
$\mathrm{P}$ model, but the corresponding maximum estimated K application amount increased by $32.93-116.66 \%$. In view of the above results, we could draw a preliminary conclusion that using the $\mathrm{L}+\mathrm{P}$ model to estimate the optimal $\mathrm{K}$ rate could avoid excessive application of $\mathrm{K}$-fertilizer without significantly reducing apple yield. Therefore, we selected the $\mathrm{L}+\mathrm{P}$ model to estimate the optimal $\mathrm{K}$ rate for apples, which were 208.33 and $176.61 \mathrm{~kg} \mathrm{~K}$ ha $^{-1}$ in the Loess Plateau region and the Bohai Bay region, respectively.
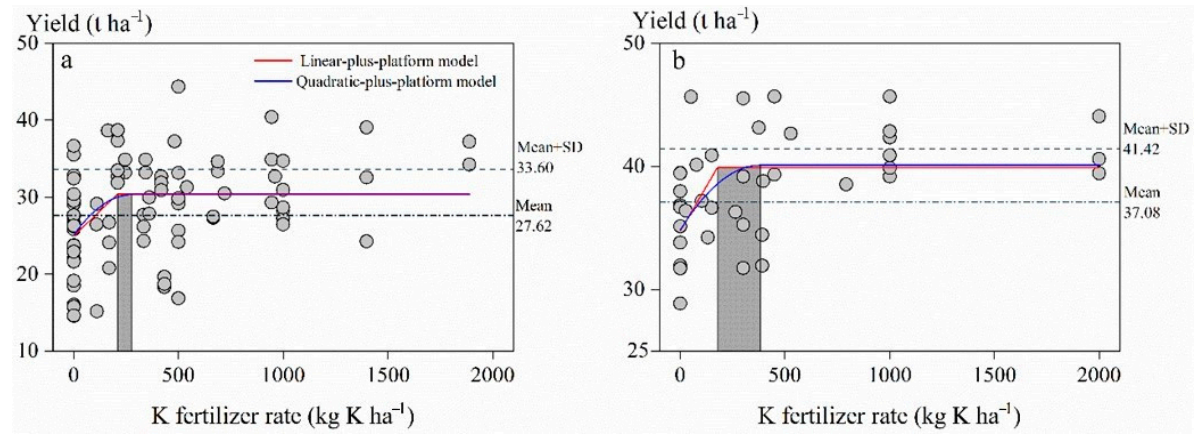

Figure 2. The functional relationship between apple yield and $\mathrm{K}$ application rates in Loess Plateau (a) and Bohai Bay (b) of China. Loess Plateau: $y=-6.83 \times 10^{-5} x^{2}+0.0378 x+25.0911 x<276.93, y=$ $30.33 x \geq 276.93$ (quadratic-plus-platform model) and $y=0.026 x+24.97 x<208.33, y=30.39 x \geq$ 208.33 (Linear-plus-plateau model). Bohai Bay: $y=-3.594 \times 10^{-5} x^{2}+0.0275 x+34.83355 x<$ 382.653, $y=40.096 x \geq 382.653$ (quadratic-plus-platform model) and $y=0.029 x+34.766 x<$ 176.614, $y=39.888 x \geq 176.614$ (Linear-plus-plateau model). Shadow areas represented the difference of K-fertilizer application rate (long side) between the quadratic plus platform and linear plus platform model under the scenario of predicting almost equivalent yields (broadside). Mean, average yield of apple field with K-fertilizer; SD, standard deviation.

In addition, there were no significant differences between the maximum yields predicted by the $\mathrm{L}+\mathrm{P}$ and $\mathrm{Q}+\mathrm{P}$ models, but the optimal $\mathrm{K}$ rate estimated by the former was much lower than that estimated by the latter, which was similar to the research results [59-61]. In this study, the optimal K rate for the Loess Plateau estimated by the L + $P$ model was similar to the results reported by Guo et al. [62]. This further proved that the $\mathrm{L}+\mathrm{P}$ model was an effective method to reasonably estimate the relationship for apple yield-K application rate.

For the $\mathrm{L}+\mathrm{P}$ and $\mathrm{Q}+\mathrm{P}$ models, a common feature is that there is a horizontal straight line (platform) after reaching optimal yield. However, in our research, their simulation effects were quite different, which might be due to the influence of not only various factors (e.g., soil and climatic conditions, especially rainfall) and fertilizer types, but their own characteristics. Before the yield reached the platform, the $\mathrm{L}+\mathrm{P}$ model could reflect that the yield increased linearly with increasing $\mathrm{K}$ application, the increasing rate of yield-K application remained constant, although the $\mathrm{Q}+\mathrm{P}$ model also reflected that the yield increased with increasing $\mathrm{K}$ application, but the increasing rate of yield-K application decreased gradually (Figure 2). As the increasing rate of yield-K application of the $Q+$ $P$ model was generally less than that of the $\mathrm{L}+\mathrm{P}$ model, it had a bigger hysteresis effect than the $\mathrm{L}+\mathrm{P}$ model when reaching almost the same optimal yield (the shaded part in Figure 2), resulting in a relatively high optimal $\mathrm{K}$ rate.

\subsection{Indigenous K supply (IKS) in Different Production Regions}

It is essential to analyze the indigenous K supply (IKS) in order to estimate the optimal $\mathrm{K}$ rate for apple orchards in different regions. So, we counted the distribution of IKS in the Loess Plateau and Bohai Bay of China (Figure 3). The average IKS for these two regions was $28.33 \mathrm{t} \mathrm{ha}^{-1}$, ranging from 14.57 to $39.47 \mathrm{tha}^{-1}$, of which $63.95 \%$ were concentrated between 22-34 t h $\mathrm{h}^{-1}$ (Figure 3a). Generally speaking, less K-fertilizer was applied in areas with a higher IKS under certain target yields [50]. The mean IKS for the Bohai Bay area was $34.55 \mathrm{t} \mathrm{ha}^{-1}$, which was $37.24 \%$ higher than that for the Loess Plateau (Figure $3 \mathrm{~b}$ ), 
the fewest optimal $\mathrm{K}$ application $\left(176.61 \mathrm{~kg} \mathrm{~K} \mathrm{ha}^{-1}\right)$, and the maximum predicted yield (39.89 $\mathrm{tha}^{-1}$ ) were estimated for the corresponding area (Namely Bohai Bay) (Figure 2), indicating that IKS played a key role in the rational formulation of $\mathrm{K}$ management policies and final yield. Simultaneously, this also seems to confirm that the amount of K-fertilizer required for harvest response yield does decrease as IKS increase. Jing et al. [63] also reached similar conclusions on the role of INS (abbreviation for indigenous N supply) in two paddy rice species.
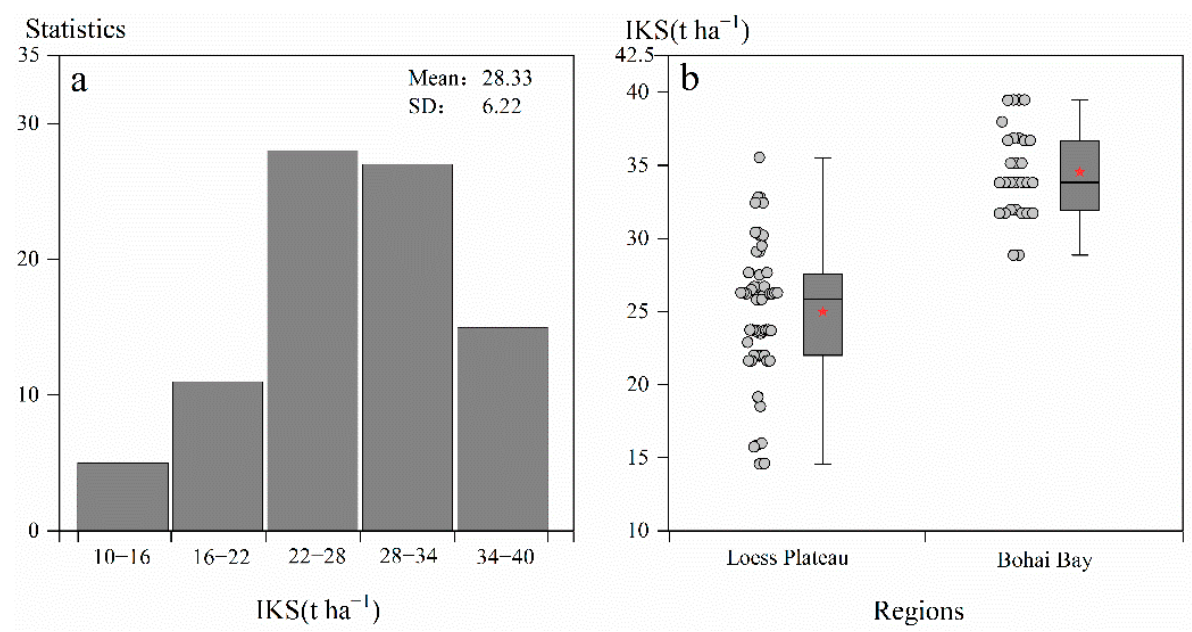

Figure 3. Statistics of soil indigenous K supply (IKS) from apple production areas in Loess Plateau and Bohai Bay of China (a) and comparison of IKS between these two areas (b). Mean, average IKS of the entire study area; SD, standard deviation. $\star$ represents the average IKS at regional scale.

Apple trees have the instinct to store nutrients in advance. They are pre-absorbed and stored by a roots' sensitive response to changes in soil $\mathrm{K}$ and their own needs to prevent potential demand when K supply is deficient. In the soil with abundant IKS, apple trees can absorb and store more $\mathrm{K}$ in advance, so the application of less $\mathrm{K}$ fertilizer can maintain soil K nutrients and be absorbed and used by apple roots, and at the same time obtain the potential optimal yield. Similarly, apple trees can only absorb and store less K in advance in soils with lacking IKS. Therefore, the potential optimal yield can be obtained only by applying more $\mathrm{K}$ fertilizer to supplement soil $\mathrm{K}$ nutrients and for apple roots to absorb and utilize.

\subsection{K Use Efficiency and Agronomic Efficiency of K under Different K Input}

K use efficiency (KUE) and the agronomic efficiency of K (KAE) are two important indicators for measuring agriculture production sustainability [64-66]. Figure 4 depicts the variation trend of KUE and KAE under different $\mathrm{K}$ rates so as to establish their response curves to K rates. Both KAE and KUE in the study area decreased exponentially with an increase in $\mathrm{K}$ rates and were comparatively higher under low $\mathrm{K}$ application conditions (Figure 4). The mean values were $80.97,93.76 \mathrm{~kg} \mathrm{~kg}^{-1}$ for KUE, and $11.78,24.13 \mathrm{~kg} \mathrm{~kg}^{-1}$ for KAE in the Loess Plateau and Bohai Bay, which were lower than 145.87, $225.85 \mathrm{~kg} \mathrm{~kg}^{-1}$ for $\mathrm{KUE}$, and $26.02,29.00 \mathrm{~kg} \mathrm{~kg}^{-1}$ for KAE under the optimal $\mathrm{K}$ rates, respectively (Figure 2). This fact showed that the estimated Optimum $\mathrm{K}$ rate based on the L+P model could not only greatly increase the yield (Figure 2) but significantly increase the KAE and KUE (Figure 4). This was similar to the conclusion reported by Lammerts van Bueren [67] that NUE was comparatively high at low $\mathrm{N}$ rates and reduced with increasing $\mathrm{N}$ rates. The high NUE might be due to the higher leaf area index and leaf $\mathrm{N}$ concentration, which led to greater accumulation of dry matter and greater $\mathrm{N}$ uptake from the soil [68]. In addition, formulating a reasonable amount of K-fertilizer was likely to achieve high KAE under low K levels. Synchronizing K-fertilizer supply with crop K demand through reasonable $\mathrm{K}$-fertilizer regulation will improve both KUE and KAE. 

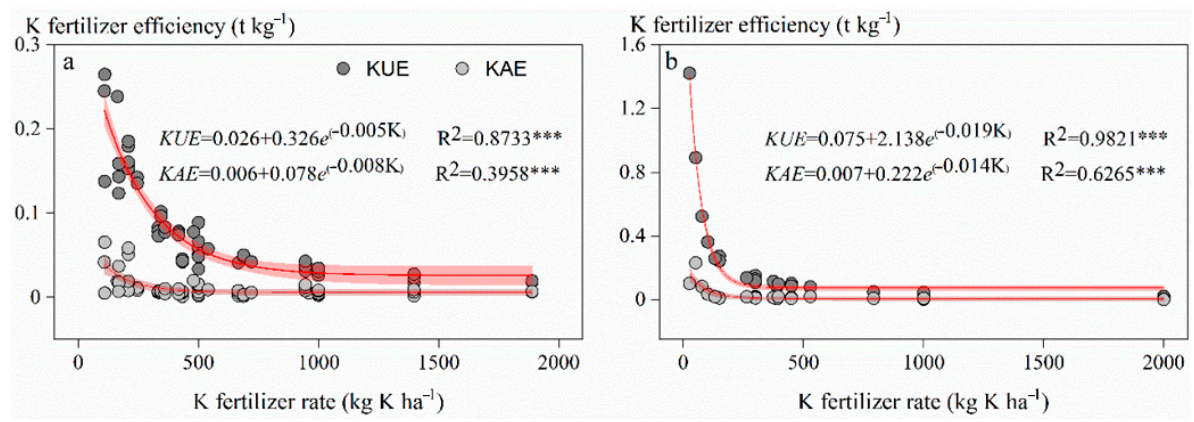

Figure 4. K use efficiency (KUE) and agronomic efficiency of K (KAE) in apple-growing regions of (a) China's Loess Plateau and (b) Bohai Bay. ${ }^{* * *}$ indicates significance at the 0.001 level.

\subsection{Yield and K Fertilizer Efficiency of the Optimum K Rate}

An optimal $\mathrm{K}$ rate that takes into account both high yield and fertilizer efficiency is what fruit growers hope most in apple production. However, the phenomenon of applying less or more K-fertilizer was more common in most apple orchard management practices. Therefore, we hoped to further elaborate on the importance of optimizing K management in apple production by comparing the differences in yield, KUE, and KAE between high $\mathrm{K}$, optimized $\mathrm{K}$, and low $\mathrm{K}$ rates. Firstly, the $\mathrm{L}+\mathrm{P}$ model was used to calculate the region optimal $\mathrm{K}$ rate, and the high $\mathrm{K}$ and low $\mathrm{K}$ rates were defined as the $\mathrm{K}$-fertilizer application rate higher than and lower than the region optimal $\mathrm{K}$ rate. For our research regions, 78.94 and $75.86 \%$ of the $\mathrm{K}$ application rates were higher than the optimal $\mathrm{K}$ rate, and 12.28 and $24.14 \%$ were less than the optimal $\mathrm{K}$ rate in different $\mathrm{K}$ fertilizer treatments at all sites in the Loess Plateau and Bohai Bay, respectively. Then, the average values of all low $\mathrm{K}$ and high $\mathrm{K}$ treatments in different regions were calculated as representatives of low $\mathrm{K}$ and high $\mathrm{K}$ fertilizer, respectively. The corresponding yield was calculated by the $\mathrm{L}+\mathrm{P}$ model, and the corresponding KUE (or KAE) was calculated based on the exponential relationship between K application rates and KUE (or KAE), respectively.

Compared with the yield of low K-fertilizer, the optimal $\mathrm{K}$ rate yield increased by $6.03 \%$ in the Loess Plateau and Bohai Bay regions. The study by Xu et al. [69] showed that low K-fertilizer inhibited root development by significantly reducing root-shoot ratio, root activity, and the organ biomass of apple trees, thereby reducing yield, while optimal $\mathrm{K}$ fertilizer could make carbohydrates transfer from vegetative organs to storage organs by increasing photosynthetic efficiency, carbon and nitrogen metabolism enzyme activities, thereby increasing fruit weight and yield [69,70]. Although the optimal $\mathrm{K}$ rate has almost the same yields as the high $\mathrm{K}$ rate in all regions (Figure $5 \mathrm{~b}$ ), KUE at the optimal $\mathrm{K}$ rate enhanced by 45.88 and $70.52 \%$ and raised KAE by 68.57 and $77.45 \%$ for the Loess Plateau and the Bohai Bay districts, respectively (Figure $5 c$,d). It was fully revealed that a high $\mathrm{K}$ application rate not only leads to a serious waste of $\mathrm{K}$ resources and increases the financial burden of fruit growers but also may aggravate soil fertility degradation in orchards [71]. Zhang et al. [72] studied the response of fruit quality to K application rate and showed that plenty accumulation of $\mathrm{K}$ in the soil was caused by overuse $\mathrm{K}$ application during the orchard rest stage. The optimal $\mathrm{K}$ rate could assure both a high yield and KUE; a low $\mathrm{K}$-fertilizer rate limited the potentiality for production growth, while a high K-fertilizer rate caused overabundance $\mathrm{K}$ in the soil and endangered soil health. The optimal $\mathrm{K}$ rate estimated in our study could synergistically improve apple yields and KUE. Therefore, the optimal $\mathrm{K}$ rate could be used as advice or reference for K-fertilizer management in apple orchards in the study zones. 

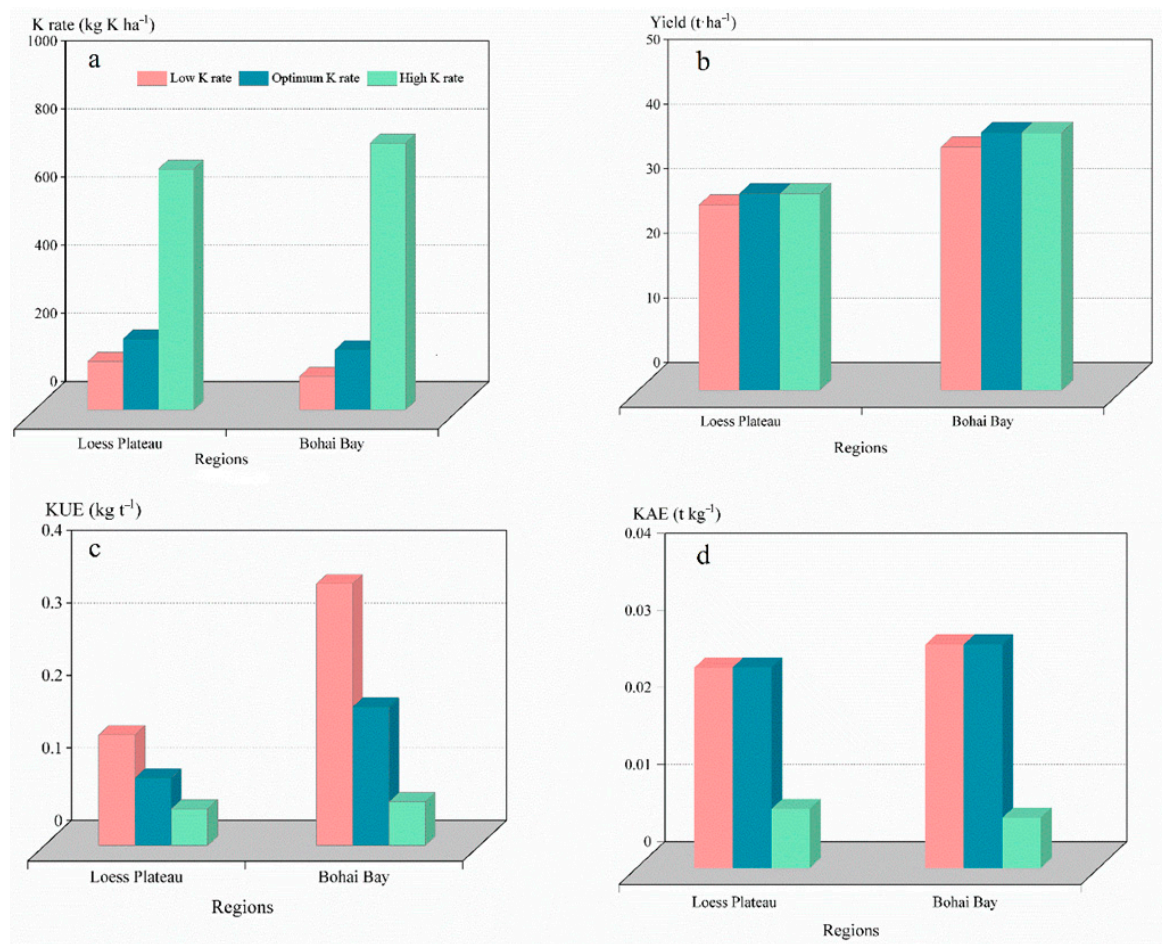

Figure 5. K rate (a) apple yield, (b) K use efficiency (KUE), (c) and agronomic efficiency of K (KAE), (d) under three $\mathrm{K}$-fertilizer levels (low $\mathrm{K}$ rate, optimal $\mathrm{K}$ rate and high $\mathrm{K}$ rate) in apple planting regions of China's Loess Plateau and Bohai Bay.

\subsection{Uncertainty of Optimum K Rate}

\subsubsection{Based on Different Research Targets}

Different research objectives will lead to different optimal $\mathrm{K}$ rates, making it clear that the research aim was essential when formulating an optimal K-fertilizer management policy. Allison et al. [73] reported the optimal $\mathrm{K}$ rate policy based on response to yield, and Jiang et al. [74] reported the optimal $\mathrm{K}$ rate to maximize economic benefits. Crop yield was directly or indirectly involved no matter what kinds of research goals were pursued. Therefore, maximizing crop yield was often regarded as the first goal when determining the optimal $\mathrm{K}$ rate [75]. In this study, the optimal $\mathrm{K}$ rate was certainly different from that determined by yield if the research goal was to pursue economic income, ecological benefits, social benefits, or other goals [76].

\subsubsection{Based on Specific Sites}

The reference $\mathrm{K}$ application rate obtained from existing studies with similar soil and climate conditions was reasonable and feasible when making the optimization K-fertilizer management strategies at small-scale fields. However, it was not scientific enough to improve the K-fertilizer management for large-scale regions only by relying on the results obtained from studies conducted in individual sites. The results obtained from different field trials on a regional scale could provide relatively reliable guidance and reference for large-scale regions K-fertilizer management [52]. In our study, the estimated optimal K rate was derived from the comprehensive results of multiple field trials on a regional scale, taking into account the impact of different levels of $\mathrm{K}$ application rates. Recommending appropriate $\mathrm{K}$ inputs should be adjusted to match the production conditions of specific-site research to account for the differences in uncontrollable factors (e.g., soil and climatic conditions) between different test sites. Jiang et al. [77] conducted a nutritional analysis on apple orchards in three soil types of brown loam, alluvial soil, and brown soil in Shandong Province, China. The results showed that the available K content in brown loam was significantly higher than that in brown soil and significantly lower than that in alluvial soil. Apple trees are not only highly dependent on climatic conditions, especially 
precipitation, but also extremely sensitive. Drought leads to the deterioration of the soil's physicochemical environment, and apple trees find absorbing required nutrients difficult. When rain causes waterlogging, soil nutrients are easily lost to affect fruit yield. Except for uncontrollable factors, the $\mathrm{K}$ application rates should also be mediated on the types of K-fertilizer, timing of K-applied, apple trees species, and management practices [78]. The research results of Feng et al. [79] and Chen et al. [80] both showed that the rational application of KCL fertilizer in apple orchards had a slightly better yield-increasing effect than $\mathrm{K}_{2} \mathrm{SO}_{4}$. The results of Zhao et al. [76] showed that the combined application of organic fertilizers and chemical fertilizers significantly increased apple yields compared to a single application of chemical fertilizers. Pramod Kumar et al. [81] reported that the rational management of K-fertilizer, fertilizer ratio, and fertilization timing during the apple growth period could obtain a higher yield than that of traditional K-fertilizer. Applying the optimized $\mathrm{K}$ management practices could reduce the amount of $\mathrm{K}$-fertilizer needed to achieve the target yield. Based on this, the adjustment of $\mathrm{K}$ application rates needed to integrate consideration controllable factors (such as types of K-fertilizer, the timing of K-applied, apple trees species, and management practices) and uncontrollable factors (such as soil and climate) in some specific locations. The unreasonable K application rate (excessive or insufficient K-fertilizer) formulated based on fruit growers' experience rather than $\mathrm{K}$ demand for physiological growth of apple trees was widespread and has long been applied in most regions. The over-fertilization of K cannot greatly increase the yield of areas with sophisticated management practices and proper plant conditions, but it will intensify environmental risk and soil degradation in this region. Moreover, we should minimize the input of K-fertilizer in areas with high $\mathrm{K}$ application. The negative effect of inadequate $\mathrm{K}$ application on yield should also not be neglected [82-84]. Reasonably increasing $\mathrm{K}$ application rates in some regions with a low IKS or improper climatic conditions will help avoid output loss (Appendix A [85-100]).

\section{Conclusions}

Through the comparison and evaluation of five models of the relationship between $\mathrm{K}$ application rate and yield for advantageous apple-producing regions of China, the $\mathrm{L}$ + P model was established as the best estimation model of the relationship between $\mathrm{K}$ application rate and yield at the regional scale, and the optimum $\mathrm{K}$ rates for the Loess Plateau and Bohai Bay were estimated to be 208.33 and $176.61 \mathrm{~kg} \mathrm{~K} \mathrm{ha}^{-1}$, respectively. We found that the optimal $\mathrm{K}$ rate estimated based on the model significantly improved the KUE and KAE without almost causing apple yield loss. The target yield could be achieved by applying less K-fertilizer in regions with a larger IKS. The apple yield would be reduced by $6.03 \%$ when the $\mathrm{K}$ application rate was lower than the optimum $\mathrm{K}$ rate. Although an equivalent yield could be obtained from the optimum $\mathrm{K}$ rate and a high $\mathrm{K}$ application rate, the optimal K application rate could improve KUE and KAE by $45.88-68.57 \%$ and $70.52-$ $77.45 \%$, respectively. In view of the results, it should be considered wise to moderately reduce $\mathrm{K}$ application rate by reference to the optimal $\mathrm{K}$ rate in apple planting regions that overuse $\mathrm{K}$-fertilizer, and increase $\mathrm{K}$ application rate in low $\mathrm{K}$-fertilizer rate areas to improve apple yield and maintain the sustainable development of soil K-fertilizer fertility. Overall, the assessment of regional K-fertilizer application rates provides evidence for how to coordinate the regulation of optimal $\mathrm{K}$ rate management, crop yield maintenance, and sustainable soil fertility.

Author Contributions: Conceptualization, X.H., N.C. and W.W.; methodology, W.T. and D.C.; validation, H.Y. and X.H.; formal analysis, W.T., D.C. and H.Y..; investigation, W.T., and H.Y.; writingreview and editing, W.T., D.C. and X.H.; supervision, X.H., W.W. and N.C.; funding acquisition, X.H. and W.W. All authors have read and agreed to the published version of the manuscript.

Funding: This research was funded by Study and Demonstration of Water-Fertilizer Integration Technology Mode of Shaanxi Grape, grant number [2017YFD0201508-07].

Institutional Review Board Statement: Not applicable. 
Informed Consent Statement: Informed consent was obtained from all subjects in-volved in the study.

Data Availability Statement: The authors declare that the data supporting this study are available from the corresponding author on reasonable request.

Acknowledgments: We are thankful to all the researchers whose contributions have been used for study analysis and referenced in this review article.

Conflicts of Interest: All authors declare no known competing financial interests or other relationships in the submitted work.

\section{Appendix A}

References of the meta-analysis [41,70,85-100].

\section{References}

1. Philip, L.F.; Herb, S.A.; Elizabeth, E.D.; James, J.L.; Hokanson, S.C. Collection, Maintenance, Characterization, and Utilizationof Wild Apples of Central Asia. Hort. Rev. 2003, 29, 1-61.

2. Boyer, J.; Liu, R.H. Apple phytochemicals and their health benefits. Nutr. J. 2004, 3, 5. [CrossRef]

3. Ulaszewska, M.; Vazquez-Manjarrez, N.; Garcia-Aloy, M.; Llorach, R.; Mattivi, F.; Dragsted, L.O.; Pratico, G.; Manach, C. Food intake biomarkers for apple, pear, and stone fruit. Genes Nutr. 2018, 13, 29. [CrossRef] [PubMed]

4. Han, M.Y. Annual Report on the Development of Apple Industrial Technology; MOA: Beijing, China, 2008.

5. FAO. FAOSTAT Production Database; FAO: Rome, Italy, 2016.

6. Godfray, H.C.; Beddington, J.R.; Crute, I.R.; Haddad, L.; Lawrence, D.; Muir, J.F.; Pretty, J.; Robinson, S.; Thomas, S.M.; Toulmin, C. Food security: The challenge of feeding 9 billion people. Science 2010, 327, 812-818. [CrossRef]

7. Inouye, A.M.W. China: Fresh Deciduous Fruit Annual; USDA Foreign Agricultural Service: Washington, DC, USA, 2019.

8. Ma, W.L.; Abdulai, A. Linking apple farmers to markets Determinants and impacts of marketing contracts in China. China Agric. Econ. Rev. 2016, 8, 2-21. [CrossRef]

9. Musacchi, S.; Serra, S. Apple fruit quality: Overview on pre-harvest factors. Sci. Hortic. 2018, 234, 409-430. [CrossRef]

10. Wang, N.; Wolf, J.; Zhang, F.-S. Towards sustainable intensification of apple production in China-Yield gaps and nutrient use efficiency in apple farming systems. J. Integr. Agric. 2016, 15, 716-725. [CrossRef]

11. Kim, S.O.; Chung, U.R.; Kim, S.H.; Choi, I.M.; Yun, J.I. The Suitable Region and Site for 'Fuji' Apple Under the Projected Climate in South Korea. Korean J. Agric. Forest Meteorol. 2009, 11, 162-173. [CrossRef]

12. Zhang, Q.; Zhou, B.B.; Li, M.J.; Wei, Q.P.; Han, Z.H. Multivariate analysis between meteorological factor and fruit quality of Fuji apple at different locations in China. J. Integr. Agric. 2018, 17, 1338-1347. [CrossRef]

13. Li, W.; Yang, M.; Wang, J.; Wang, Z.; Fan, Z.; Kang, F.; Wang, Y.; Luo, Y.; Kuang, D.; Chen, Z.; et al. Agronomic Responses of Major Fruit Crops to Fertilization in China: A Meta-Analysis. Agronomy 2019, 10, 15. [CrossRef]

14. Liu, C.W.; Sung, Y.; Chen, B.C.; Lai, H.Y. Effects of nitrogen fertilizers on the growth and nitrate content of lettuce (Lactuca sativa L.). Int. J. Environ. Res. Public Health 2014, 11, 4427-4440. [CrossRef] [PubMed]

15. Pettigrew, W.T. Potassium influences on yield and quality production for maize, wheat, soybean and cotton. Physiol. Plant 2008, 133, 670-681. [CrossRef]

16. Ashley, M.K.; Grant, M.; Grabov, A. Plant responses to potassium deficiencies: A role for potassium transport proteins. J. Exp. Bot. 2006, 57, 425-436. [CrossRef]

17. Prajapati, K.; Modi, H.A. The importance of potassium in plant growth-A review. Indian J. Plant Sci. 2012, 1, 177-186.

18. Qi, J.; Sun, S.; Yang, L.; Li, M.; Ma, F.; Zou, Y. Potassium Uptake and Transport in Apple Roots Under Drought Stress. Hortic. Plant J. 2019, 5, 10-16. [CrossRef]

19. Cakmak, I. Potassium for better crop production and quality. Plant Soil 2010, 335, 1-2. [CrossRef]

20. Nava, G.; Dechen, A.R. Long-Term Annual Fertilization with Nitrogen and Potassium Affect Yield and Mineral Composition of 'Fuji' Apple. Sci. Agric. 2009, 66, 377-385. [CrossRef]

21. Basile, B.; Reidel, E.J.; Weinbaum, S.A.; DeJong, T.M. Leaf potassium concentration, CO2 exchange and light interception in almond trees (Prunus dulcis (Mill) D.A. Webb). Sci. Hortic. 2003, 98, 185-194. [CrossRef]

22. Bednarz, C.W.; Oosterhuis, D.M. Physiological changes associated with potassium deficiency in cotton. J. Plant Nutr. 1999, 22, 303-313. [CrossRef]

23. Cassman, K.G.; Kerby, T.A.; Roberts, B.A.; Bryant, D.C.; Brouder, S.M. Differential Response of Two Cotton Cultivars to Fertilizer and Soil Potassium. Agron. J. 1989, 81, 870-876. [CrossRef]

24. Marschner, P. Marschner's Mineral Nutrition of Higher Plants. In Marschner's Mineral Nutrition of Higher Plants; Marschner, P., Ed.; Academic Press: Cambridge, MA, USA, 2012.

25. Oosterhuis, D.M.; Loka, D.A.; Kawakami, E.M.; Pettigrew, W.T. The Physiology of Potassium in Crop Production. Adv. Agron. 2014, 126, 203-233.

26. Suelter, C.H. Enzymes activated by monovalent cations. Science 1970, 168, 789-795. [CrossRef] 
27. Wang, Y.; Wu, W.H. Potassium transport and signaling in higher plants. Annu. Rev. Plant Biol. 2013, 64, 451-476. [CrossRef] [PubMed]

28. Teo, G.; Suziki, Y.; Uratsu, S.L.; Lampinen, B.; Ormonde, N.; Hu, W.K.; DeJong, T.M.; Dandekar, A.M. Silencing leaf sorbitol synthesis alters long-distance partitioning and apple fruit quality. Proc. Natl. Acad. Sci. USA 2006, 103, 18842-18847. [CrossRef] [PubMed]

29. Malvi, U. Interaction of micronutrients with major nutrients with special reference to potassium. Karnataka J. Agric. Sci. 2011, 24, 106-109.

30. Sheldrick, W.F.; Syers, J.K.; Lingard, J. Soil nutrient audits for China to estimate nutrient balances and output/input relationships. Agric. Ecosyst. Environ. 2003, 94, 341-354. [CrossRef]

31. Andrist-Rangel, Y.; Edwards, A.C.; Hillier, S.; Öborn, I. Long-term K dynamics in organic and conventional mixed cropping systems as related to management and soil properties. Agric. Ecosyst. Environ. 2007, 122, 413-426. [CrossRef]

32. Hoa, N.; Janssen, B.; Oenema, O.; Dobermann, A. Comparison of partial and complete soil K budgets under intensive rice cropping in the Mekong Delta, Vietnam. Agric. Ecosyst. Environ. 2006, 116, 121-131. [CrossRef]

33. Sardans, J.; Peñuelas, J. Potassium: A neglected nutrient in global change. Global Ecol. Biogeogr. 2015, 24, 261-275. [CrossRef]

34. Savci, S. Investigation of Effect of Chemical Fertilizers on Environment. APCBEE Proc. 2012, 1, 287-292. [CrossRef]

35. Jemrić, T.; Fruk, I.; Fruk, M.; Radman, S.; Sinkovič, L.; Fruk, G. Bitter pit in apples: Pre- and postharvest factors: A review. Span. J. Agric. Res. 2016, 14, 15. [CrossRef]

36. Liu, M.Y.; Song, L.Q.; Zhao, L.L. Occurrence and prevention of apple bitter pit. Yantai Fruits 2019, 2, 34-35.

37. Sun, L.Y.; Gao, R.S.; Qin, S.J. Research Progress on the Occurrence and Integrated Control of Apple Bitter Pit. North. Fruits 2021, 1, $1-3$.

38. Wu, X.; Wang, D.; Riaz, M.; Zhang, L.; Jiang, C. Investigating the effect of biochar on the potential of increasing cotton yield, potassium efficiency and soil environment. Ecotoxicol. Environ. Saf. 2019, 182, 109451. [CrossRef] [PubMed]

39. Dhillon, J.S.; Eickhoff, E.M.; Mullen, R.W.; Raun, W.R. World Potassium Use Efficiency in Cereal Crops. Agron. J. 2019, 111, 889-896. [CrossRef]

40. Rengel, Z.; Damon, P.M. Crops and genotypes differ in efficiency of potassium uptake and use. Physiol. Plant 2008, 133, 624-636. [CrossRef]

41. Li, H.T.; Zhou, J.B.; Wen, X.W.; Dang, T.; Ma, W.Z.; Lei, Z.X. The effect of nitrogenous, phosphatic, and potassium fertilizers on Fuji Apple Trees. Res. Soil Water Conserv. 1996, 3, 163-168.

42. Jin, H.C.; Zhang, L.S.; Li, B.Z.; Han, M.Y.; Liu, X.G. Effect of potassium on the leaf nutrition and quality of Red Fuji Apple. Acta Agric. Boreali Occident. Sin. 2007, 16, 100-104.

43. Malo, D.; Schumacher, T.; Doolittle, J. Long-term cultivation impacts on selected soil properties in the northern Great Plains. Soil Tillage Res. 2005, 81, 277-291. [CrossRef]

44. Tan, D.; Jin, J.; Jiang, L.; Huang, S.; Liu, Z. Potassium assessment of grain producing soils in North China. Agric. Ecosyst. Environ. 2012, 148, 65-71. [CrossRef]

45. Tan, D.; Liu, Z.; Jiang, L.; Luo, J.; Li, J. Long-term potash application and wheat straw return reduced soil potassium fixation and affected crop yields in North China. Nutr. Cycl. Agroecosyst. 2017, 108, 121-133. [CrossRef]

46. Zhang, C.Y.; Chang, Q.; Huo, X.X. Analysis on the layout of China's apple production transition. Econ. Geogr. 2018, 38, 141-151.

47. Fernandez, J.A.; DeBruin, J.; Messina, C.D.; Ciampitti, I.A. Late-season nitrogen fertilization on maize yield: A meta-analysis. Field Crops Res. 2020, 247, 107586. [CrossRef]

48. Li, S.; Duan, Y.; Guo, T.; Zhang, P.; He, P.; Johnston, A.; Shcherbakov, A. Potassium management in potato production in Northwest region of China. Field Crops Res. 2015, 174, 48-54. [CrossRef]

49. Singh, V.K.; Dwivedi, B.S.; Tiwari, K.N.; Majumdar, K.; Rani, M.; Singh, S.K.; Timsina, J. Optimizing nutrient management strategies for rice-wheat system in the Indo-Gangetic Plains of India and adjacent region for higher productivity, nutrient use efficiency and profits. Field Crops Res. 2014, 164, 30-44. [CrossRef]

50. Cong, R.; Li, H.; Zhang, Z.; Ren, T.; Li, X.; Lu, J. Evaluate regional potassium fertilization strategy of winter oilseed rape under intensive cropping systems: Large-scale field experiment analysis. Field Crops Res. 2016, 193, 34-42. [CrossRef]

51. Li, G.-H.; Cheng, Q.; Li, L.; Lu, D.-l.; Lu, W.-P. N, P and K use efficiency and maize yield responses to fertilization modes and densities. J. Integr. Agric. 2021, 20, 78-86. [CrossRef]

52. Liu, Y.; Ma, J.; Ding, W.; He, W.; Lei, Q.; Gao, Q.; He, P. Temporal and spatial variation of potassium balance in agricultural land at national and regional levels in China. PLoS ONE 2017, 12, e0184156. [CrossRef]

53. Qiu, S.; Xie, J.; Zhao, S.; Xu, X.; Hou, Y.; Wang, X.; Zhou, W.; He, P.; Johnston, A.M.; Christie, P.; et al. Long-term effects of potassium fertilization on yield, efficiency, and soil fertility status in a rain-fed maize system in northeast China. Field Crops Res. 2014, 163, 1-9. [CrossRef]

54. Yang, X.; Li, C.; Zhang, Q.; Liu, Z.; Geng, J.; Zhang, M. Effects of polymer-coated potassium chloride on cotton yield, leaf senescence and soil potassium. Field Crops Res. 2017, 212, 145-152. [CrossRef]

55. Wang, C.; Zang, H.D.; Liu, J.G.; Shi, X.Y.; Li, S.; Chen, F.; Chu, Q.Q. Optimum nitrogen rate to maintain sustainable potato production and improve nitrogen use efficiency at a regional scale in China. A meta-analysis. Agron. Sustain. Dev. 2020, 40, 1-14. [CrossRef] 
56. Yu, F.; Feng, S.; Du, W.; Wang, D.; Guo, Z.; Xing, S.; Jin, Z.; Cao, Y.; Xu, T. A Study of Nitrogen Deficiency Inversion in Rice Leaves Based on the Hyperspectral Reflectance Differential. Front. Plant Sci. 2020, 11, 573272. [CrossRef]

57. Zamuner, E.C.; Lloveras, J.; Echeverría, H.E. Use of a Critical Phosphorus Dilution Curve to Improve Potato Crop Nutritional Management. Am. J. Potato Res. 2016, 93, 392-403. [CrossRef]

58. Qeyami, M. Effects of Calcium and Potassium Application on Growht, Yield and Quality of Apple (Malus x domestica Borkh.) cv Red Delicious. Indian J. Pure Appl. Biosci. 2020, 8, 574-584. [CrossRef]

59. Chen, X.P.; Zhou, J.C.; Wang, X.R.; Zhang, F.S. Economic and environmental evaluation on models for describing crop yield response to nitrogen fertilizers at winter-wheat and summer-corn rotation system. Acta Pedol. Sin. 2000, 37, 346-354.

60. Wang, X.M.; Jie, X.L.; Chen, S.L.; Hou, Y.L.; Li, Z.G. Verification of Fertilization Model and Recommended Fertilization in the Crop Rotation of Winter Wheat and Summer Maize. J. Anhui Agric. Sci. 2008, 36, 4181-4184.

61. Zeng, C.L.; Wang, X.R.; Cheng, X.P.; Zhang, F.S. Study on the select of nitrogen fertilization models for winter wheat and the effects of it on result of fertilizing nitrogen. J. Jianghan Univ. 2000, 17, 8-12.

62. Guo, Q.E.; Guo, T.W.; Ran, S.B. Study on the effect of potassium fertilizer on apple. Gansu Agric. Sci. Technol. 2001, 9, 36-37.

63. Jing, Q.; Bouman, B.A.M.; Hengsdijk, H.; Van Keulen, H.; Cao, W. Exploring options to combine high yields with high nitrogen use efficiencies in irrigated rice in China. Eur. J. Agron. 2007, 26, 166-177. [CrossRef]

64. Duan, Y.; Zhang, J.; An, H.; Jing, Y.P.; Jin, C.W.; Zhao, N.; Li, S.T. Effectively increasing the yield and oil quality of sunflower by basal application of potassium fertilizers in Hetao irrigation area, Inner Mongolia. J. Plant Nutr. Fertil. 2018, 24, 1349-1356.

65. Hartley, T.N.; Thomas, A.S.; Maathuis, F.J.M. A role for the OsHKT 2;1 sodium transporter in potassium use efficiency in rice. J. Exp. Bot. 2020, 71, 699-706. [CrossRef]

66. Olk, D.C.; Cassman, K.G.; Simbahan, G.; Cruz, P.C.S.; Abdulrachman, S.; Nagarajan, R.; Tan, P.S.; Satawathananont, S. Interpreting fertilizer-use efficiency in relation to soil nutrient-supplying capacity, factor productivity, and agronomic efficiency. Nutr. Cycl. Agroecosyst. 1999, 53, 35-41. [CrossRef]

67. Van Bueren, E.T.L.; Struik, P.C. Diverse concepts of breeding for nitrogen use efficiency. A review. Agron. Sustain. Dev. 2017, 37, 37-50.

68. Qiang, S.; Zhang, Y.; Fan, J.; Zhang, F.; Xiang, Y.; Yan, S.; Wu, Y. Maize yield, rainwater and nitrogen use efficiency as affected by maize genotypes and nitrogen rates on the Loess Plateau of China. Agric. Water Manag. 2019, 213, 996-1003. [CrossRef]

69. Xu, X.; Du, X.; Wang, F.; Sha, J.; Chen, Q.; Tian, G.; Zhu, Z.; Ge, S.; Jiang, Y. Effects of Potassium Levels on Plant Growth, Accumulation and Distribution of Carbon, and Nitrate Metabolism in Apple Dwarf Rootstock Seedlings. Front. Plant Sci. 2020, 11, 904. [CrossRef]

70. Wang, Q.; He, W.H.; Guo, J.N.; Huang, X.G.; Jiao, S.M.; He, Y.H. Effect of application of potassium fertilizer on production and fruit quality apple trees. J. Fruit Sci. 2002, 19, 424-426.

71. Kuzin, A.I.; Trunov, Y.V.; Solovyev, A.V. Effect of fertigation on yield and fruit quality of apple (Malus domestica Borkh.) in high-density orchards on chernozems in Central Russia. Acta Hortic. 2018, 1217, 343-350. [CrossRef]

72. Zhang, Z.Y.; Li, Y.J.; Cui, W.S.; Liu, M.Y.; Du, X.Z.; Jiang, X.L. Effects of increasing potassium fertilizer on apple fruits and orchard soil. Shandong Agric. Sci. 2013, 45, 97-99, 102.

73. Allison, M.F.; Fowler, J.H.; Allen, E.J. Responses of potato (Solanum tuberosum) to potassium fertilizers. J. Agric. Sci. 2001, 136, 407-426. [CrossRef]

74. Jiang, W.T.; Liu, X.H.; Wang, Y.; Zhang, Y.; Qi, W. Responses to Potassium Application and Economic Optimum K Rate of Maize under Different Soil Indigenous K Supply. Sustainability 2018, 10, 2267. [CrossRef]

75. Vos, J. Nitrogen Responses and Nitrogen Management in Potato. Potato Res. 2010, 52, 305-317. [CrossRef]

76. Zhao, Z.P.; Yan, S.; Liu, F.; Ji, P.H.; Wang, X.Y.; Tong, Y.A. Effects of chemical fertilizer combined with organic manure on Fuji apple quality, yield and soil fertility in apple orchard on the Loess Plateau of China. Int. J. Agric. Biol. Eng. 2014, 7, 45-55.

77. Yuanmao, J.; Manru, G.; Huairui, S. Nutrient diagnosis of starking delicious' apple. Acta Hortic. Sin. 1995, 22, 215-220.

78. Roberts, T.L. Improving nutrient use efficiency. Turk. J. Agric. Forest. 2008, 32, 177-182.

79. Feng, S.K.; Yang, S.C.; Nie, H.R. Preliminary report on application techniques of potassium fertilizer in apple orchard on sloping land in Western Liaoning. China Fruits 1987, 4, 38-40.

80. Chen, C.; Tong, Y.A.; Lu, Y.L.; Gao, Y.M. Effects of different potassium fertilizers on production, quality and storability of Fuji apple. J. Plant Nutr. Fertil. 2016, 22, 216-224.

81. Kumar, P.; Sharma, S.K.; Kumar, A. Foliar nutritive fluids affect generative potential of apples: Multilocation DOP indexing and PCA studies under dry temperate agro-climatic conditions of north-west Himalaya. Sci. Hortic. 2017, 218, 265-274. [CrossRef]

82. Hou, Y.L. Theory and technological system of ecological balanced fertilization. Acta Ecol. Sin. 2000, 20, 653-658.

83. Hou, Y.L. Theory system, index system of ecological balanced fertilization and demonstration for fertilizer efficiency evaluation. J. Agroenviron. Sci. 2011, 30, 1257-1266.

84. Yan, J.C.; Lei, H.Z. The development tendency and inspiration of ecological agriculture in the world. World Agric. 2005, 1, 7-10.

85. An, F.S.; Xing, Q.M.; Zhao, Q.; Sheng, X.F.; Cui, L.X. Study on Application of Biological Potash Fertilizer in Apple Orchard. Yantai Fruits 1997, 4, 15-17.

86. An, F.Z.; Zhang, F.S. Effects on yield and quality in close planting apple orchard with potash fertilization. South. Hortic. 2012, 23, $16-18$. 
87. Feng, S.K.; Yang, R.L.; Nie, H.R. Comparative experiment of two kinds of potassium fertilizer on apple fertilizer efficiency. North. Fruits 1989, 3, 19-21.

88. Feng, Z. Effect of Different Potassium Levels on the Yield and Quality of Red Fuji Apple. Anhui Agric. Sci. Bull. 2015, 3, 56-57.

89. Gao, Y.M.; Tong, Y.A.; Lu, Y.L.; Wang, X.Y. Effects of Soil Available Nutrients and Long-term Fertilization on Yield of Fuji Apple Orchard of Weibei Area in Shaanxi, China. Acta Hortic. Sin. 2013, 40, 613-622.

90. Li, T.T.; Zhai, B.N.; Li, Y.G.; Liu, L.L.; Han, M.Y. Effect of fertilizer type on growth and yield of Fuji apple in Weibei dry region of Shaanxi. J. Fruit Sci. 2013, 30, 591-596.

91. Lin, H.T.; Jiang, L.H.; Liu, Z.H.; Song, X.Z.; Zheng, F.L.; Wang, M.; Zhang, W.J. Effects of applying potassium magnesium sulfate on apple yield, quality and leaf mineral nutrition. Shandong Agric. Sci. 2007, 6, 86-88.

92. Liu, R.L.; Tong, Y.A.; Gao, Y.M.; Zhao, Y. Study on soil nutrients in apple orchard and balanced fertilization in shaanxi Weibei dry-land. J. Northwest Sci-Tech Univ. Agric. For. 2008, 36, 135-140.

93. Shi, C.Y. Effects of Different NPK Treatments on the Yield of Luochuan Red Fuji Apple. Shanxi Agric. Econ. 2017, 5, 57-59.

94. Tang, X.R.; Zhang, F.Q. Effect of Potassium Fertilizer Application on Fruit Yield and Quality in Apple Orchard. Yantai Fruits 2007, 3, 19-20.

95. Zhang, L.X.; Geng, Z.C.; Li, S.X. Research on interaction between water and different forms of potassium and quality responses of Fuji apple on Weibei rainfed highland. Acta Univ. Agric. Boreali-occident. 2002, 30, 21-26.

96. Zhang, P.P.; Xu, X.Y.; Qiu, D.X.; Zang, M.J. Application of kalium fercilizer in palm soil increases the yield and improves the quatoty of various crops. J. Shandong Agric. Univ. 2003, 34, 424-426.

97. Zhao, Z.P.; Duan, M.; Tong, Y.A. Effects of different fertilizations on yield and fruit quality of Fuji apple in different ecological regions. Agric. Res. Arid Areas 2016, 34, 158-165.

98. Zhao, Z.P.; Tong, Y.A. Effect of different fertilization on apple yield, fruit quality and storage duration of Fuji apple. J. China Agric. Univ. 2016, 21, 26-34.

99. Zhao, Z.P.; Tong, Y.A.; Gao, Y.M.; Fu, Y.Y. Effect of different fertilization on yield and quality of Fuji apple. J. Plant Nutr. Fertil. 2005, 19, 1130-1135.

100. Zheng, W.; Li, Y.; Gong, Q.; Zhang, H.; Zhao, Z.; Zheng, Z.; Zhai, B.; Wang, Z. Improving yield and water use efficiency of apple trees through intercrop-mulch of crown vetch (Coronilla varia $\mathrm{L}$.) combined with different fertilizer treatments in the Loess Plateau. Span. J. Agric. Res. 2016, 14, 30. [CrossRef] 